\title{
Collaborative Approach is an Alternative Learning Process to the Japanese Language
}

\author{
Uning Kuraesin
}

Widyatama University, Indonesia

Copyright $@ 2019$ by authors, all rights reserved. Authors agree that this article remains permanently open access under the terms of the Creative Commons Attribution License 4.0 International License

\begin{abstract}
Very rapid changes in all sectors, especially in the field of work, encourage higher education institutions to equip their graduates with adaptability and creativity to be able to follow these changes and developments. To answer these challenges, the role of the teacher in delivering subject matter to students is not easy. One of the abilities that must be possessed by a teacher in improving his professional competence is the ability to develop learning models that are applied in the classroom. The background of writing this paper is the inactivity of students in following the learning process. However, the author find out that we need to innovate in learning, and that the level of student understanding of the material is less than expected. From the target, $75 \%$ of the students can be active when process in learning. Learning methods are carried out using collaborative learning through group discussions. The author considers that student-centered learning would change the behavior of students who were initially less active. On that basis, in this paper the author raises the theme, Collaborative Approach as one of the learning models that can improve understanding of the material. In the learning process, the author chooses a collaborative approach through group discussion with the aim that students can exchange ideas/ information (sharing of information) between them. In this method, students work together in small groups to achieve the same goal. In collaborative learning activities, things that need to be considered for students are that they work together in solving the same problem, and not individually solve the problem separately during collaboration students' work together to build the same understanding and concepts to complete each part of the problem or task assigned. This paper is an exploratory study on students to know the direction of student learning in understanding a material. The actions that the author has done in class are a series of activities from a process to improve students' abilities. From the teaching experience with a collaborative approach through group discussion, it can be seen that there are changes in learning behavior that initially some students are relatively passive, dare to express their
\end{abstract}

opinions. Positioning students in active roles, potential collaborative approaches can be chosen as one of the effective strategies. This research is (1) to investigate why a potential collaborative approach can improve learning outcomes, (2) to investigate the role of lecturers, and (3) to investigate the strategic role of students. To illustrate how this idea can be practiced in the context of the class, this presentation concludes with a presentation on empirical experience implementing a collaborative approach with examples of excellence, challenges and weaknesses.

Keywords SCL, Learning Process, Collaborative Approach, the Role of Lecturers and Students

\section{Introduction}

The change of paradigm in the learning process that was originally centered on the lecturer to student-centered learning is the need for education reform in universities. Through the Student Centered Learning (SCL) approach, it is expected that the learning strategy is centered on students as the main actors in classroom activities. This approach aims to encourage students to actively participate in building knowledge, attitudes and behaviors that are very important rather than just transferring knowledge. In addition, behavior can work together, making decisions either independently or in groups is a provision to fill a more quality of their life.

Based on cognitive factors, the achievement of good learning outcomes from a student, of course, is an expectation desired by the lecturer. However, if we refer to the goal of competency-based learning which seeks to improve the quality of life in entering the industrial world, this is certainly not optimal.

The condition of students' knowledge that is not the same in class becomes the basis for the writer in conducting this research. The collaborative approach is one of the SCL strategies, which considered to provide the 
learner with an opportunity to jointly actively participate in understanding a material without regard to individual differences, working in a team to achieve common goals, so that understanding and mastery of the material will be more evenly distributed.

The object of this study was the third and fifth semester students. This was done by two classes. For semester 3, a collaborative approach is applied to Bunpo II courses, and semester 5 is in Honyaku II courses: Tourism. The method used in the two classes is the same, that's the learning process through a collaborative approach.

\section{Method}

Classroom Action Research (CAR), arises because of the occurrence of problems or dissatisfaction from the teacher towards students' learning outcomes. From this research, it is hoped that it will find solutions to the problems that arise in the classroom.

The main concept of action research according to Kurt Lewin consists of four components as a whole cycle: (1) planning, (2) acting, (3) observation (observing), and (4) reflection (reflecting). In the implementation of this action, the author does this by referring to the cycle above, there are:

\section{Planning}

\section{a. Place of Research}

Research in the Japanese Language Study Program at Widyatama University. Implementation time using a collaborative approach 3 times.

\section{b. Object of Research}

The study was conducted on fourth semester students of Level II with a Bunpo II course as many as 6 people consisting of 4 females and 2 males. And the third semester students of the third semester on the course of Honyaku II: Tourism with a total of 6 students consisting of 3 females and 3 males, so that the total population of respondents is 12 people. This action was treated against all respondents through discussion.

\section{c. Research Instruments}

a). Observation sheet used to record student activities when carrying out discussions and understanding of the material presented.

b). Worksheets

\section{d. Action Plan}

Implementation of actions (discussions and presentations)

\section{e. Observation}

Observation and recording student activities when conducting discussions, and during presentations.

\section{f. Reflection}

At this reflection session, the author studies the successes and shortcomings of the implementation of learning through a collaborative approach.

\section{Theoretical Review}

Active learning aims to build knowledge and skills of learners by collaborating and collaborating with various related parties. In this study, the author uses a collaborative approach to the learning process in the classroom. Collaborative learning is a learning model that applies a new paradigm to learning theories (Yufiarti 2003; Yaraghi \& Shafiee, 2018; Hossain, 2018). This approach can be described as a learning model by fostering students to work together in small groups to achieve the same goals.

\section{Discussion and Results}

\section{Discussion}

The main characteristic of student-centered learning is the role of the lecturer in the learner shifts from being a teacher (teacher) to being a facilitator in the student learning process.

Lecturers become learning partners who function as mentors (guide on the side) for the students.

The steps taken in this class action research begin to divide students into groups heterogeneously, because small classes then the number of groups are divided into 2 small groups, determining the material to be discussed from each group, creating stimulants to motivate students to interact in the discussion, giving students the flexibility to discuss in groups to the maximum extent possible to improve individual thinking skills and knowledge, lecturers make observations and presentations, lecturers make observations of the learning process, and lastly reflect

\section{Role of Learner}

In collaborative learning, the students must be actively involved in the material discussed. Students learn to integrate new materials with the knowledge they have previously owned. Students build meaning or create something new related to course material. Students actively manage knowledge and interact with each other, find relevant data and information to solve problems, and do not focus solely on mastering the material, but also develop learning attitudes (life-long learning).

\section{Results}

\section{a. Student Learning Outcomes}

As a learning target, at least $75 \%$ of students get a 'B' for 
each subject. For Bunpo II courses, the acquisition of the average UTS score before the action is 61.3. And the course of Honyaku II: Tourism, the acquisition of the average score before the action is 66. The learning outcomes obtained through a collaborative approach, that the acquisition of values undergoes a change. The Bunpo II course, obtaining an average UAS score of 65.6, although not yet significant, and the Honyaku II Course: Tourism, the acquisition of the average UAS score was 74.57.

\section{b. Changes in behavior}

That changes in the industrial sector that continue to grow are also very influential in the increasingly rigorous qualification of employee recruitment. It is no longer seen on the cognitive side, but also soft skill factors that can improve employee performance.

Collaborative approach through discussion techniques in the implementation of learning, at least will be able to change the habits of one's behavior. With the habits that are carried out during discussion: respecting others, exchanging ideas with a heterogeneous environment is a provision in dealing with the real world of work.

\section{Conclusions}

Collaborative approach through discussion is one strategy to improve cognitive, affective, and psychomotor learners (Jabarullah and Hussain, 2019). From the study obtained, there were significant results both academic achievement and student behavior changes. Students can learn to respect the opinions of others, manage time, and be able to express opinions. SCL learning can only take place well if both parties carry out their roles well.

\section{REFERENCES}

[1] Alhassan, A. B., \& Anya, C. A. (2017). Forms and Consequences of Examination Malpractices' in Nigeria's Schools and Universities: What Should the Stakeholders Do?. International Journal of Education, Training and Learning, 1(1), 9-21.

[2] Ali, L. (2018). The Influence of Information Technology on Student's Behavioural Nature in the Class Room. Asian Journal of Education and Training, 4(2), 102-107.

[3] Demirel, I. N., Teyfur, M., Çelik, I., Safali, S., \& Kaya, A. (2018). Perspectives of Preservice Teachers on the Statements Related to Preservice Teachers and Competence of Lecturers. Journal of Education and e-Learning Research, 5(3), 185-192.

[4] Direktorat Akademik Dikti. 2008. Buku Pedoman Pengembangan Kurikulum Berbasis Kompetensi Pendidikan Tinggi. Jakarta;

[5] Hossain, M. (2018). Solitude and its Language Manifestation in Ernest Hemingways the Old Man and the
Sea: A Psycholinguistic Inspection. International Journal of English Language and Literature Studies, 7(3), 75-80.

[6] Jabarullah, N.H. and Hussain, H.I. (2019) The Effectiveness of Problem-Based Learning in Technical and Vocational Education in Malaysia, Education + Training, https://doi.org/10.1108/ET-06-2018-0129.

[7] PAU-PPAI Universitas Terbuka. 1997. Mengajar di Perguran Tinggi Direktorat Jenderal Pendidikan Tinggi Departemen Pendidikan dan Kebudayaan. Jakarta;

[8] Pupuh Fathurrahman. 2007. Strategi Belajar Mengajar melalui Penanaman Konsep Umum \& Konsep Islami. Refika Aditama. Bandung;

[9] Suharsimi Arikunto, Suhardjono, Supardi. 2012. Penelitian Tindakan Kelas. Bumi Aksara. Jakarta;

[10] Wang, Q., Yang, Z., Wang, T., Zhu, M., \& Qu, Z. (2017). Study on the Reasons Why the Ability of Junior High School Students about Data Analysis is Weak. Global Journal of Social Sciences Studies, 3(1), 56-62.

[11] Yang, Z., Wang, T., Zhu, M., \& Qu, Z. (2017). How Did Mathematics Postgraduates Obtain Tacit Knowledge of Mathematical Problem Solving?. American Journal of Education and Learning, 2(2), 121-131.

[12] Yaraghi, E., \& Shafiee, S. (2018). Roles of Learner Autonomy and Willingness to Communicate in Communication Strategy Use of EFL Learners. International Journal of English Language and Literature Studies, 7(3), 55-74. 